\title{
Histological modifications of the rat prostate following transection of somatic and autonomic nerves
}

\author{
ROSAURA DIAZ, LUIS I. GARCIA, JOSE LOCIA, MILAGROS SILVA, SARA RODRIGUEZ, \\ CESAR A. PEREZ, GONZALO E. ARANDA-ABREU, JORGE MANZO, \\ REBECA TOLEDO and MARIA ELENA HERNANDEZ \\ Programa de Neurobiologia, Universidad Veracruzana, Av. Luis Castelazo s/n \\ Col. Industrial Animas, Xalapa, Ver., C.P. 91190, Mexico
}

Manuscript received on January 8, 2009; accepted for publication on January 25, 2010

\begin{abstract}
It is known that hormones influence significantly the prostate tissue. However, we reported that mating induces an increase in androgen receptors, revealing a neural influence on the gland. These data suggested that somatic afferents (scrotal and genitofemoral nerves) and autonomic efferents (pelvic and hypogastric nerves) could regulate the structure of the prostate. Here we assessed the role of these nerves in maintaining the histology of the gland. Hence, afferent or efferent nerves of male rats were transected. Then, the ventral and dorsolateral regions of the prostate were processed for histology. Results showed that afferent transection affects prostate histology. The alveoli area decreased and increased in the ventral and dorsolateral prostate, respectively. The epithelial cell height increased in both regions. Efferent denervation produced dramatic changes in the prostate gland. The tissue lost its configuration, and the epithelium became scattered and almost vanished. Thus, afferent nerves are responsible for spinal processes pertaining to the trophic control of the prostate, activating its autonomic innervation. Hence, our data imply that innervation seems to be synergic with hormones for the healthy maintenance of the prostate. Thus, it is suggested that some prostate pathologies could be due to the failure of the autonomic neural pathways regulating the gland.
\end{abstract}

Key words: pelvic nerve, hypogastric nerve, genitofemoral nerve, scrotal nerve.

\section{INTRODUCTION}

The prostate is the largest sexual gland in the male reproductive tract, and its structure and function have been widely investigated by a number of authors. Most reports, including ours (Hernandez et al. 2006, 2007), have emphasized the importance of hormones in the growth, function, and pathological development of this gland. Thus, the leading therapy for prostate cancer is still based on endocrine manipulation. However, one issue that has been less investigated is the role of the peripheral nerves not only on the physiology of the gland, but also on the development of cancer cells.

Previously, we argued that the execution of sex-

Correspondence to: Dr. Maria Elena Hernandez

E-mail: elenahernandez@uv.mx ual behavior induces an increase in androgen receptors in the prostate tissue of male rats, which could be explained as a neural influence on the gland (Hernandez et al. 2007). Also, we showed that the stimulation of the scrotal skin during copulation is important for the ejaculation of a normal quantity of semen, in which the prostate plays a key role (Garcia et al. 2007). Therefore, we hypothesized that somatic afferent fibers (scrotal and genitofemoral nerves) and the autonomic innervation of the prostate (pelvic and hypogastric nerves) seem to integrate into a spinal circuit that regulates the function, and perhaps contributes to the dysfunction, of the prostate gland.

The prostate is innervated by postganglionar fibers emerging from the major pelvic ganglion that, in turn, 
is innervated by both the hypogastric nerve and the viscerocutaneous branch of the pelvic nerve (Hulsebosch and Coggeshall 1982, Langworthy 1965, Pacheco et al. 1989). This nerve complex regulates the function of the prostate via cholinergic, noradrenergic, and peptidergic pathways (Kepper and Keast 1995, Nadelhaft 2003, Pennefather et al. 2000). Recently, it has been reported that these autonomic efferents are driven by a complex circuit of central neurons stationed in different brain nuclei, all of which are involved in the control of male rat sexual behavior (Huddleston et al. 2007). Spinal mechanisms have also been proposed to influence the physiology of the prostate (Huang et al. 1997). However, the extent to which the spinal cord and peripheral nerves are involved in the autonomic regulation of the prostate is yet unknown. Thus, in this study we investigated the effects produced on the prostate tissue following the lesion of afferent or efferent nerves in the pelvic area.

\section{MATERIALS AND METHODS}

\section{SubJeCtS AND Housing}

Sexually experienced Wistar male rats from Harlan Mexico were studied (250-300 g/bw). As copulation maintains a continuous activity of the nerves and prostate gland, the rats were submitted to regular copulation trials, as stated below. Ovariectomized sexually experienced females were used during the copulatory trials and their sexual receptivity was induced with subcutaneous injections of estradiol benzoate $(10 \mu \mathrm{g}$; Sigma-Aldrich Mexico) followed by progesterone ( $2 \mathrm{mg}$; Sigma-Aldrich Mexico), both diluted in sesame oil and administered subcutaneously $48 \mathrm{hr}$ and $4 \mathrm{hr}$ before mating, respectively. The rats were kept in Plexiglas cages $(50 \times$ $30 \times 20 \mathrm{~cm}$ ) with woodchip bedding (Harlan Mexico) in a temperature-controlled room $\left(22 \pm 2^{\circ} \mathrm{C}\right)$, with free access to food (Harlan rodent chow) and water. The room was kept at a reversed 12:12 cycle (lights on at 8:00 pm).

\section{ANImAL USE AND CARE}

Every surgical intervention and manipulation was executed according to the Policy on the Use of Animals in Neuroscience Research of the Society for Neuroscience. Every effort was made to minimize animal suffering and the total number of animals used.

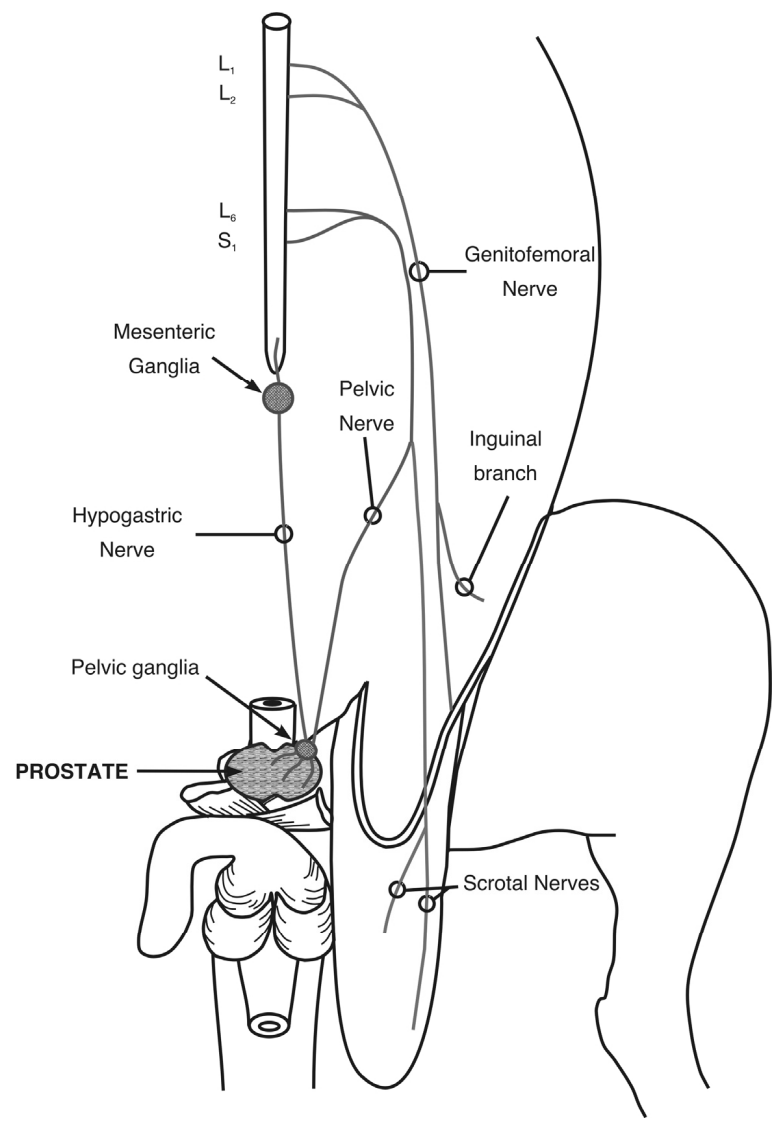

Fig. 1 - Somatic (afferent) and autonomic (efferent) nerves in the pelvic area. The integration of the nerves occurs in the lumbar and sacral segments of the spinal cord. The transected afferent nerves, scrotal and genitofemoral nerves, supply the scrotal and groin epithelium, which are mechanically stimulated during copulation. The transected efferent nerves, pelvic and hypogastric nerves, innervate the prostate gland and other structures.

\section{GROUPS AND EXPERIMENTAL RATIONALE}

The areas that are mechanically stimulated during copulation are the scrotum and groin. The scrotal area is innervated by the scrotal $(\mathrm{Sc})$ nerves, whereas the groin is innervated by the genitofemoral (Gf) nerves (Fig. 1). It is known that the transection of these nerves does not affect the proper execution of sexual behavior (Garcia et al. 2007, Lucio et al. 2001). Nevertheless, we previously hypothesized that scrotal afferents trigger spinal reflexes and activate autonomic efferents that supply sexual glands (Garcia et al. 2007). Thus, the experimental objective of this study was to identify whether these nerves influence the histological parameters of the pro- 
state. To do so, subjects were randomly assigned to three experimental groups: a group with bilateral lesions of the Sc nerve $(n=8)$, a group with bilateral lesions of the Gf nerve $(n=8)$, and a group with bilateral lesions of both $\mathrm{Sc}+\mathrm{Gf}$ nerves $(\mathrm{n}=8)$. Each group with its respective Sham operated control $(n=6)$.

The spinal integration of cutaneous afferents seems to activate the autonomic nerves that supply the sexual glands, i.e., the pelvic (Pv) and hypogastric ( $\mathrm{Hg})$ nerves (Fig. 1). Previously, it was shown that the lesion of the Pv nerves modifies the quality of sexual behavior in male rats (Lucio et al. 1994), whereas an $\mathrm{Hg}$ lesion does not modify this behavior at all (Cruz et al. 1999). Thus, following the cutaneous afferents paradigm, we carried out similar experiments: a group with bilateral lesions of the Pv nerve ( $n=7)$, a group with bilateral lesions of the $\mathrm{Hg}$ nerve $(\mathrm{n}=7)$, and a group with bilateral lesions of both $\mathrm{Pv}+\mathrm{Hg}$ nerves $(\mathrm{n}=6)$. All of them with their respective Sham control $(n=6)$.

\section{NERVE SURGERY}

Subjects were selected to participate in the experiment once they proved to be sexually experienced (males with ejaculation latencies between 5 and $15 \mathrm{~min}$ after four training tests). Next, they were randomly assigned to a group and were given the required nerve lesion carried out under sodium pentobarbital anesthesia $(30 \mathrm{mg} / \mathrm{kg}$ bw; Anestesal, Smith Kline, Mexico). A surgical microscope was used to dissect and transect the nerves.

To reach the Sc nerves, a midline longitudinal incision was made in the lower back. The muscles were separated from the vertebrae to locate the pudendal artery, which was then bent to allow a proper view of the sacral plexus. The proximal and distal Sc nerves were dissected from their origin in the plexus up to their termination in the periphery (Garcia et al. 2007, Pacheco et al. 1997), hooked, and then a $5 \mathrm{~mm}$ portion of the nerves was extracted to avoid regeneration. These procedures were done bilaterally.

The Gf nerves are the easiest to reach. After a midline abdominal longitudinal incision, the intestines were carefully moved to one side to expose the descending aorta. Left and right Gf nerves were located on either side of the descending aorta, hooked and cut, again a $5 \mathrm{~mm}$ portion of the nerves was extracted.
A similar incision was done to observe the $\mathrm{Hg}$ and Pv nerves. However, the major pelvic ganglion was first located at its closest point of contact with the prostate, and then the nerves were followed in their path to the spinal cord. A Pv nerve lesion interferes with micturition; hence, the bladder was manually compressed twice a day after surgery for the remainder of the experiment. This procedure kept animals in a healthy condition.

In all of the above-mentioned cases, muscle and skin were carefully sutured (simple interrupted suture with Catgut 3-0) and a single dose of intramuscular antibiotic was injected after the surgical intervention (0.1 ml of Pengesod, 1,000,000 U, Lakeside Mexico). Sham-operated subjects underwent surgical procedures where the nerves were hooked, but not cut. At the end of the study, the animals were re-examined to confirm that no regeneration had occurred.

\section{BEHAVIORAL PROCEDURES AND PROSTATE SURGERY}

In order to maintain a continuous activation of the pelvic reproductive system, males were placed with sexually receptive females three days following the surgery to copulate and were removed after one ejaculation. This procedure was held out at every two days for a total of five mating sessions. Following the last ejaculation (day 15 after surgery), males were anesthetized with an intraperitoneal injection of sodium pentobarbital $(30 \mathrm{mg} /$ $\mathrm{kg}$ bw; Anestesal, Smith Kline, Mexico). An abdominal midline longitudinal incision was made to reach the prostate, and tissue from the ventral (VP) and dorsolateral (DLP) regions of the gland were removed and processed for histology using the hematoxilin-eosin method. Then, nerve transections were re-examined in each animal, and they were subsequently sacrificed with a lethal dose of sodium pentobarbital.

\section{Staining the Prostate Tissue}

The hematoxilin-eosin staining procedure was performed by immersing the prostate tissue for $24 \mathrm{~h}$ in Helly fixative (Mercuric Chloride 5\%, Potassium Dichromate $2.5 \%$, Sodium Sulfate 1\%, and Formalin 37\%); then, the tissue was rinsed with tap water for $30 \mathrm{~min}$. Dehydration was carried out by immersing the prostate in ethanol $70 \%$ (1 hr), 80\% (1 hr), 96\% (3 times, $2 \mathrm{hr}$ each), absolute ethanol (overnight), and absolute ethanol (2 times, 
$1 \mathrm{hr}$ each). The tissue was cleared by immersing the prostate in xylene (3 times, $1 \mathrm{hr}$ each). Both dehydration and clearing were carried out on a stirring plate. Next, the tissue was embedded in melted paraffin ( 2 times, 2 $\mathrm{hr}$ each at $57^{\circ} \mathrm{C}$ ) and a block was carved using a microtome cassette. The paraffin block was sectioned on a Leica microtome $(5 \mu \mathrm{m})$. Sections were transferred to a mounting bath of gelatinized water at $52^{\circ} \mathrm{C}$ and mounted on slides that were warmed for $1 \mathrm{hr}$ in an oven $\left(\sim 58^{\circ} \mathrm{C}\right)$. For staining, the sections were immersed in xylene (3 times, $5 \mathrm{~min}$ each), absolute ethanol/xylene 1:1 (5 min), ethanol 96\% (3 min), iodine alcohol ( $5 \mathrm{~min}$ ), sodium thiosulfate (10 min), tap water (2 min), Mayer's Hematoxilin (10 min), tap water (30 sec), acid ethanol (fast bath), tap water $(10 \mathrm{sec})$, lithium carbonate $(30 \mathrm{sec})$, tap water (10 sec), Eosin Y (4 fast baths), ethanol 96\% (3 min), absolute ethanol (2 $\mathrm{min})$, absolute ethanol/xylene 1:1 ( $2 \mathrm{~min}$ ), and xylene (5 min). Finally, sections were coverslipped using undiluted Permount. Each slide had sections from one region of the prostate, either VP or DLP. The slides were observed under an Olympus Provis AX70 microscope, and images were obtained and analyzed with the help of Image Pro Plus software (in a Dell PC Computer with Windows XP Operating System). Measurements of the mean area of each of the alveoli and the height of epithelial cells were compiled.

\section{STATISTICS}

Nonparametric statistics were used. Between-group comparisons were made using a Kruskal-Wallis analysis of variance, and paired contrasts were obtained using the Mann-Whitney U test. Significant differences were inferred when $\mathrm{p}<0.05$.

\section{RESULTS}

\section{AfFerent Denervation}

Transection of the Sc and/or Gf did not affect the proper execution of sexual behavior, as reported elsewhere (Garcia et al. 2007, Lucio et al. 2001). However, reliable effects on prostate histology were observed (Fig. 2). The area of the alveoli in the VP significantly decreased after Sc, Gf or Sc+Gf lesions, although a Gf lesion produced the most significant decrease (Fig. 3). The DLP showed a different pattern. Sc transection, alone or combined with the Gf transection, yielded a significant in- crease in the alveoli area, while a Gf transection alone produced a decrease (Fig. 3). On the other hand, the epithelial cell height significantly increased in both the VP and the DLP after Sc and/or Gf lesions. However, in the VP, a Gf transection alone did not produce any modification in these cells (Fig. 3).

\section{EFFERENT DENERVATION}

Transection of the Pv nerves produced alterations of the sexual behavior of males, while $\mathrm{Hg}$ transection did not modify this behavior at all, as expected, according to previous literature (Cruz et al. 1999, Lucio et al. 1994). Nevertheless, transection of both $\mathrm{Pv}$ and $\mathrm{Hg}$ nerves, alone or combined, resulted in serious tissue damage in both the VP and DLP. The tissue completely lost its organization, and the epithelial cells became scattered and almost vanished. Thus, quantitative analysis was rendered impossible due to these dramatic alterations (Fig. 4).

\section{DISCUSSION}

The autonomic innervation of the prostate is important for the healthy maintenance of the gland. Our data indicate that there is a circuit between somatic afferents (Sc and Gf nerves) and autonomic efferents (Pv and $\mathrm{Hg}$ nerves) that has two levels of integration, the first at the spinal cord and the second at the major pelvic ganglion. Considering the fact that lesioning efferents had the most powerful effect on the prostate tissue, it is then suggested that highly complex spinal and ganglion processes are involved in the neural control of the prostate.

The afferent nerves from the scrotum are arranged into two different trunks: one supplying the proximal half of the scrotal skin, and the other supplying the distal half (Pacheco et al. 1997). This innervation was formerly related to the perception of mechanical stimulation and temperature changes of the scrotum (Hellon et al. 1975, Taylor et al. 1987). However, now we know that scrotal nerves are important for the expulsion of a normal quantity of semen and a number of spermatozoa during ejaculation, which impacts on the physiology of sexual glands like the prostate (Garcia et al. 2007). How can this be possible? As far as we know, these afferents do not directly innervate the prostate. Therefore, the only possibility is via the spinal cord. Hence, we suggest that mechanical stimulation of the scrotum 

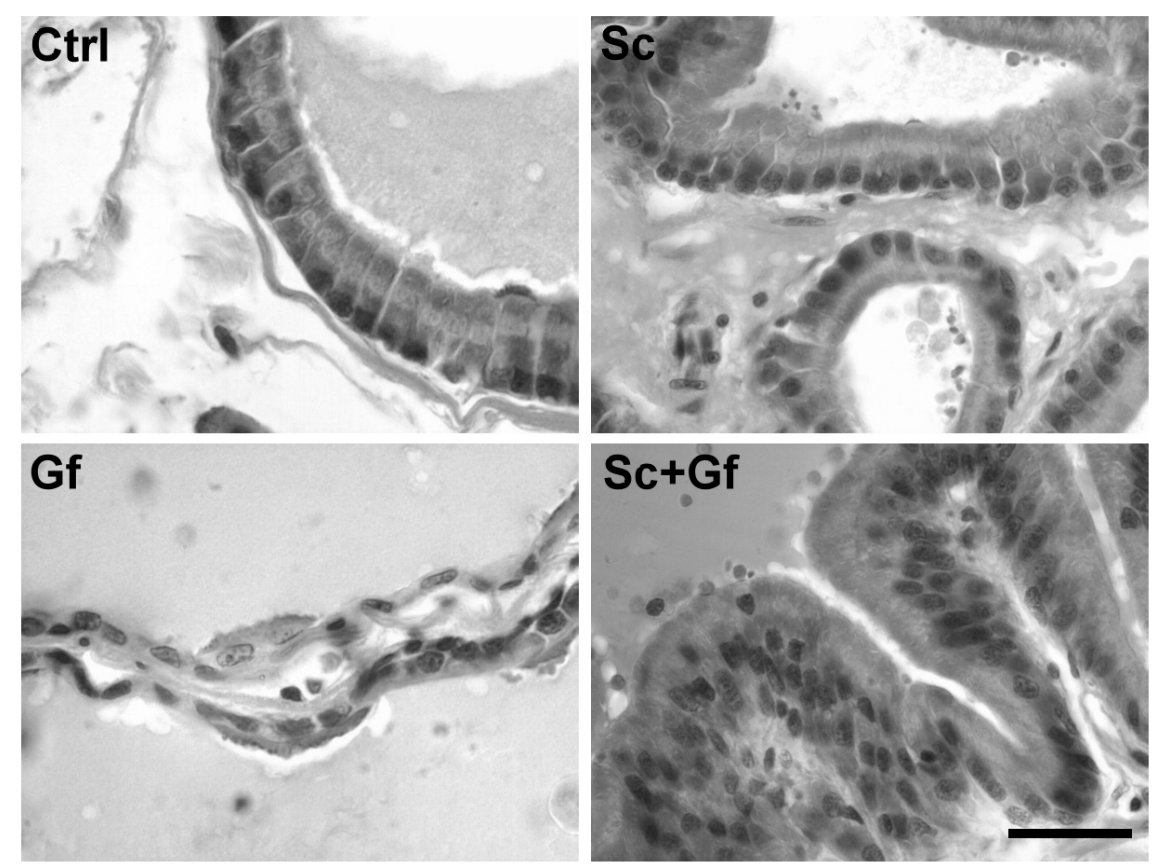

Fig. 2 - Prostate histology. Histological changes obtained after denervation of scrotal (Sc) and genitofemoral (Gf) nerves alone or in combination $(\mathrm{Sc}+\mathrm{Gf})$. Notice the clear alteration of the epithelium after denervation. $\operatorname{Bar}=200 \mu \mathrm{m}$.
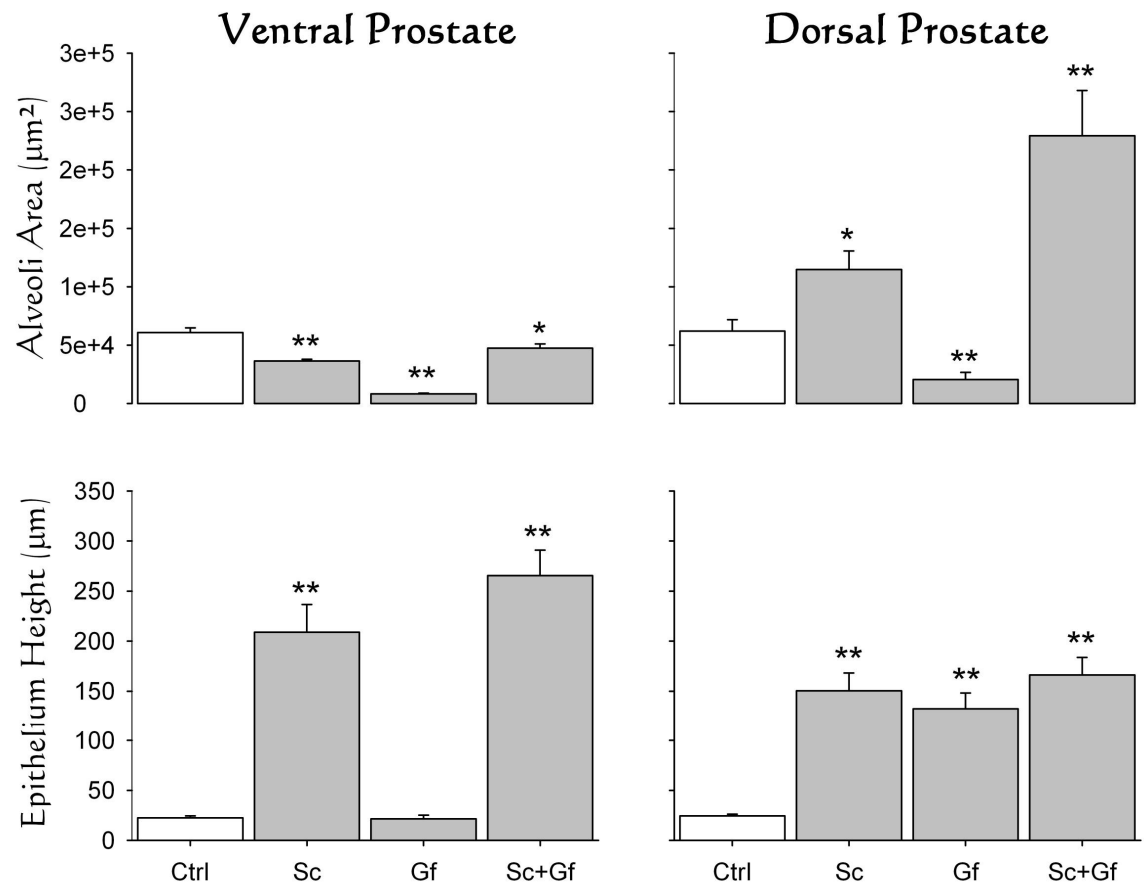

Fig. 3 - Graphic representation of histological changes. Modification of prostate tissue parameters following denervation of scrotal ( $\mathrm{Sc}$ ) and genitofemoral (Gf) nerves alone or combined ( $\mathrm{Sc}+\mathrm{Gf}$ ). Data showed individual effects of ventral and dorsal regions of the prostate. Gray bars are compared against the white bar representing the control value $(\mathrm{Ctrl}){ }^{*}=\mathrm{p}<0.05 ; * *=\mathrm{p}<0.01$. 


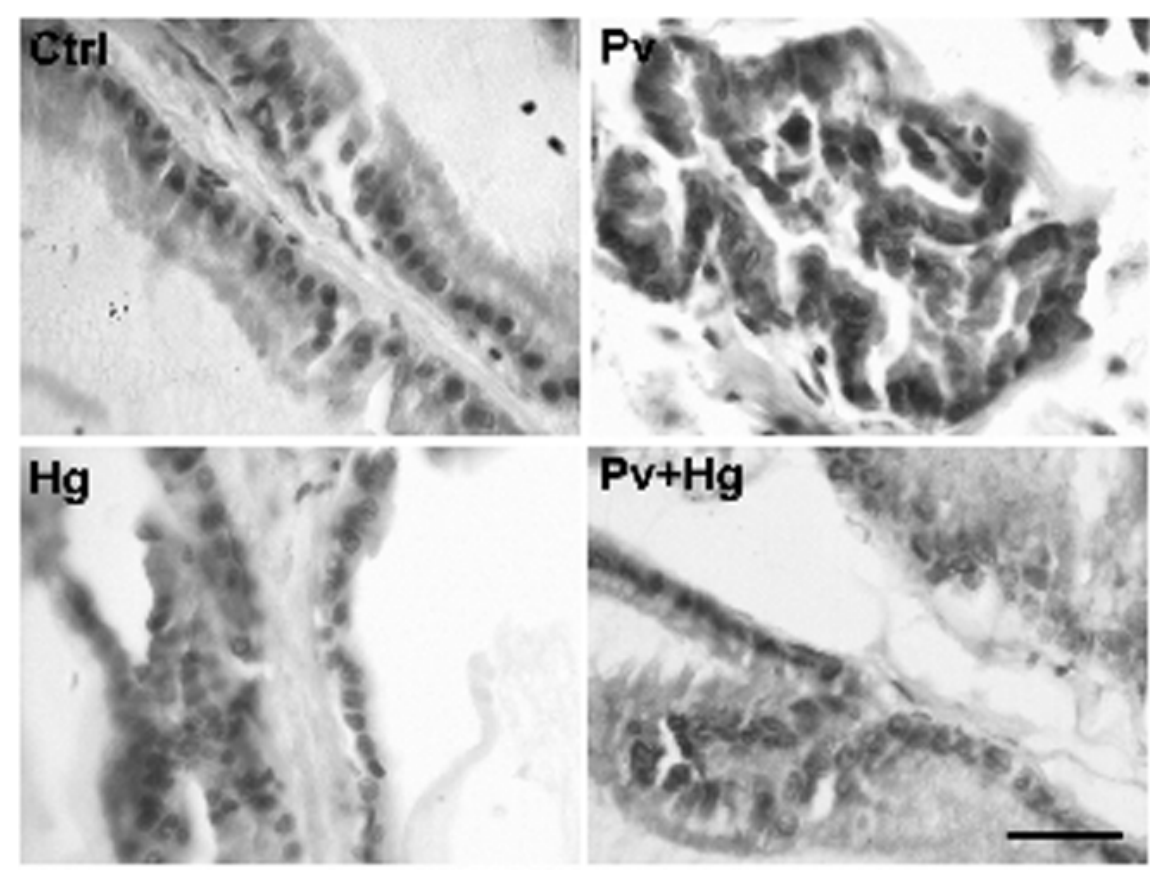

Fig. 4 - Prostate histology. Histological changes obtained after denervation of pelvic (Pv) and hypogastric $(\mathrm{Hg})$ nerves alone or in combination $(\mathrm{Pv}+\mathrm{Hg})$. Notice the devastating effect on the epithelium after these autonomic denervations. Bar $=200 \mu \mathrm{m}$.

is required to reflexively activate autonomic neurons in the spinal cord that innervate the genitourinary system; and the same occurs after the mechanical stimulation of the skin covering the groin, innervated by the genitofemoral nerve (Fig. 5). Here we showed that denervation of both the scrotum and the skin covering the groin has a differential impact on the organization of the prostate. Thus, it is suggested that both sets of fibers activate their own specific pathways in the spinal cord that, in turn, modulate the different effects observed in the prostate tissue.

The integration of afferent nerves occurs in different segments of the spinal cord. Scrotal afferents enter the spinal cord through L5, L6 and S1 segments (Manzo et al. 2003), while the genitofemoral nerves enter via L1 and L2 segments (Zempoalteca et al. 2002). On the other hand, the somas of autonomic neurons projecting to the pelvic and hypogastric nerves are located in L6-S1 (Giuliano et al. 1997) and L1-L2 (Nadelhaft and McKenna 1987) segments, respectively. Thus, afferent fibers from scrotal and groin epithelium seem to have a direct intrasegment influence on the somas of the corresponding pelvic and hypogastric neurons. This organization could account for the impact on the prostate gland following the lesion of somatic afferent nerves from scrotal and groin epithelium. In fact, lesions at these spinal segments produce great changes in the prostate tissue (Huang et al. 1997), indicating the importance of autonomic neurons in these segments for the trophic maintenance of prostate tissue.

Surgical removal of the pelvic and/or hypogastric nerves produced a dramatic alteration of the prostate tissue. This result clearly demonstrates the key role of autonomic innervation of the prostate for its healthy maintenance. Alterations following nerve lesions resembled those reported after removal of the major pelvic ganglion (Wang et al. 1991). Thus, although the prostate has been considered dependent on androgen or prolactin, our data support the idea that prostate innervation is also relevant for the gland. However, we cannot preclude the possibility that denervation produces systemic androgen alterations, therefore prostate changes, but the literature shows a controversy in this issue. Some authors have found depression in plasma testosterone following chemical sympathectomy (Stefanick et al. 1985, Lamano-Carvalho et al. 1993), while others failed to 


\section{Spinal Integration}

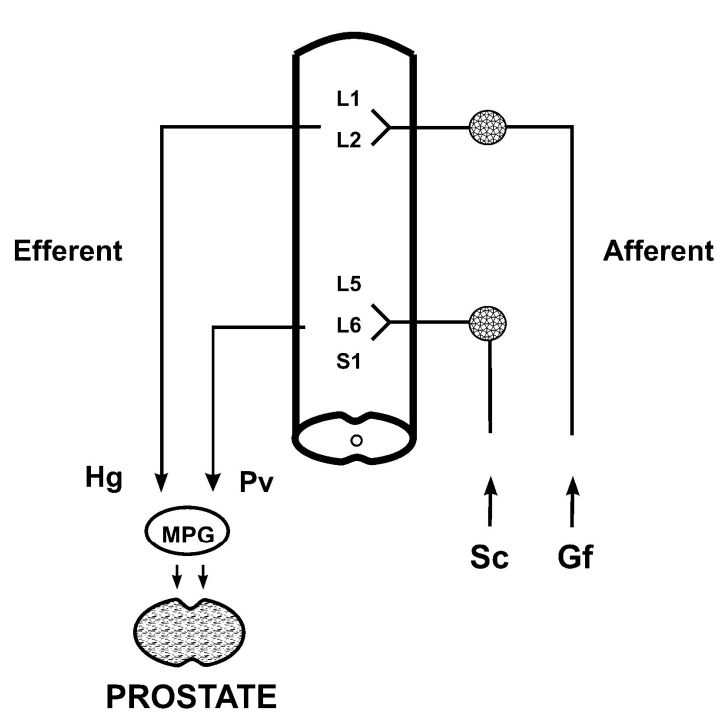

Fig. 5 - The nervous control of the prostate. Model indicating that the prostate gland is being regulated by a spinal circuit integrating somatic afferents from the scrotal (Sc) and genitofemoral nerves (Gf). These nerves project respectively to lumbar (L) and sacral (S) spinal segments to activate autonomic efferents, via the pelvic $(\mathrm{Pv})$ and hypogastric $(\mathrm{Hg})$ nerves. The efferent nerves arrive to the major pelvic ganglion (MPG), which in turn supplies the prostate tissue.

modify androgens with this procedure (Kempinas et al. 1998). No matter this controversy, what seems clear is that androgens are required for recovery after nerve injuries (Brown et al. 2001). Notwithstanding, it is widely known that hormonal alterations have been considered as the etiology of prostate cancer, and that is why androgen deprivation is one common therapy used today (Daskivich and Oh 2006). However, it is also known that, in some subjects, prostate cancer recurs even after androgen deprivation therapy (Titus et al. 2005). Hence, we suggest that recurrent cancer could be due to failure at a level of the afferent-efferent pathways regulating the prostate gland, rather than due to the failure of hormone therapy.

\section{ACKNOWLEDGMENTS}

Conacyt Scholarship to RD (Reg. No. 201985); PIFI 3.3 - CA Neurociencias (UV-CA-28). We thank Shann Menard for grammar correction.

\section{RESUMO}

Sabe-se que os hormônios influenciam significativamente o tecido prostático. Entretanto, nós demonstramos que o acasalamento induz um aumento nos receptores androgênicos, revelando uma influência neural sobre a glândula. Esses dados sugerem que os aferentes somáticos (nervos escrotal e genitofemural) e os eferentes autonômicos (nervos pélvicos e hipogástricos) poderiam regular a estrutura da próstata. Neste trabalho, avaliou-se a função destes nervos na manutenção da histologia da glândula. Dessa forma, os nervos aferentes e eferentes de ratos machos foram seccionados As regiões ventral e dorsolateral da próstata foram processadas para histologia. Os resultados mostraram que a transecção aferente afeta a histologia da próstata. A área alveolar diminuiu e aumentou na próstata dorsal e dorsolateral, respectivamente. A altura da célula epitelial aumentou em ambas as regiões. A desenervação eferente produziu alterações dramáticas na glândula prostática. O tecido perdeu a sua configuração e o epitélio tornou-se difuso e quase desapareceu. Assim, os nervos aferentes são responsáveis por processos espinhais que pertencem ao controle trófico da próstata, ativando sua inervação autonômica. Dessa forma, nossos dados sugerem que a inervação parece ser sinérgica com os hormônios para a manutenção saudável da próstata. Assim, sugere-se que algumas patologias prostáticas poderiam ser ocasionadas devido a falhas nas vias neurais autonômicas que regulam esta glândula.

Palavras-chave: nervo pélvico, nervo hipogástrico, nervo genitofemural, nervo escrotal.

\section{REFERENCES}

Brown TJ, Storer P, Oblinger M ANd Jones KJ. 2001. Androgenic enhancement of betaII-tubulin mRNA in spinal motoneurons following sciatic nerve injury. Restor Neurol Neurosci 18: 191-198.

Cruz MR, Liu YC, Manzo J, Pacheco P and Sachs BD. 1999. Peripheral nerves mediating penile erection in the rat. J Auton Nerv Syst 76: 15-27.

DASKIVICH TJ AND OH WK. 2006. Recent progress in hormonal therapy for advanced prostate cancer. Curr Opin Urol 16: 173-178.

Garcia li, Soto-Cid A, Carrillo P, Toledo R, HerNANDEZ ME AND MANZO J. 2007. Characteristics of ejaculated rat semen after lesion of scrotal nerves. Physiol Behav 91: 120-125.

Giuliano F, Facchinetti P, Bernabe J, Benoit G, CALAS A AND RAMPIN O. 1997. Evidence of sympathetic fibers in the male rat pelvic nerve by gross anatomy, 
retrograde labeling and high resolution autoradiographic study. Int J Impot Res 9: 179-185.

Hellon RF, Hensel H And Schafer K. 1975. Thermal receptors in the scrotum of the rat. J Physiol 248: 349357.

Hernandez ME, Soto-Cid A, Rojas F, Pascual Li, Aranda-Abreu GE, Toledo R, Garcia LI, QuinTANAR-Stephano A And MAnzo J. 2006. Prostate response to prolactin in sexually active male rats. Reprod Biol Endocrinol 4: 28.

Hernandez ME, Soto-Cid A, Aranda-Abreu Ge, Diaz R, Rojas F, Garcia Li, TOLEdo R AND MANZO J. 2007. A study of the prostate, androgens and sexual activity of male rats. Reprod Biol Endocrinol 5: 11.

HuANG HF, Li MT, Linsenmeyer TA, OtTENWELler JE, Pogach LM AND IRWIN RJ. 1997. The effects of spinal cord injury on the status of messenger ribonucleic acid for TRPM 2 and androgen receptor in the prostate of the rat. J Androl 18: 250-256.

Huddleston GG, Song CK, Paisley JC, Bartness TJ AND CLANCY AN. 2007. Gonadal steroid receptors colocalize with central nervous system neurons projecting to the rat prostate gland. Am J Physiol Regul Integr Comp Physiol 292: R2196-R2205.

Hulsebosch CE And Coggeshall RE. 1982. An analysis of the axon populations in the nerves to the pelvic viscera in the rat. J Comp Neurol 211: 1-10.

KePPER M AND KeAST J. 1995. Immunohistochemical properties and spinal connections of pelvic autonomic neurons that innervate the rat prostate gland. Cell Tissue Res 281: 533-542.

KEMPINAS WD ET AL. 1998. Fertility of rat epididymal sperm after chemical and surgically induced sympathectomy. Biol Reprod 59: 897-904.

Lamano-Carvalho TL, Favaretto AL, Petenusci SO AND KEMPINAS WG. 1993. Prepubertal development of rat prostate and seminal vesicle following chemical sympathectomy with guanethidine. Braz J Med Biol Res 26: 639-646.

LANGWORTHY OR. 1965. Innervation of the pelvic organs of the rat. Invest Urol 2: 491-511.

Lucio RA, Manzo J, Martinez-Gomez M, SAChs BD AND PACHECO P. 1994. Participation of pelvic nerve branches in male rat copulatory behavior. Physiol Behav 55: 241-246.

Lucio RA, Flores-Rojas G, Aguilar F, ZempoalteCA R, Pacheco P and Velazquez-Moctezuma J. 2001. Effects of genitofemoral nerve transection on cop- ulatory behavior and fertility in male rats. Physiol Behav 73: 487-492.

Manzo J, Garcia Li, CAmacho MA, Hernandez ME AND PACHECO P. 2003. Influence of testosterone on the electrical properties of scrotal nerves at the cutaneous and spinal levels in the male rat. J Peripher Nerv Syst 8: $75-81$.

NAdelhaft I. 2003. Cholinergic axons in the rat prostate and neurons in the pelvic ganglion. Brain Res 989: 5257.

Nadelhaft I And McKenna KE. 1987. Sexual dimorphism in sympathetic preganglionic neurons of the rat hypogastric nerve. J Comp Neurol 256: 308-315.

Pacheco P, Martinez-Gomez M, Whipple B, Beyer C AND KOMISARUK BR. 1989. Somato-motor components of the pelvic and pudendal nerves of the female rat. Brain Res 490: 85-94.

Pacheco P, Camacho MA, Garcia Li, Hernandez ME, Carrillo P AND Manzo J. 1997. Electrophysiological evidence for the nomenclature of the pudendal nerve and sacral plexus in the male rat. Brain Res 763: 202-208.

Pennefather JN, LAU WA, Mitchelson F AND VenTURA S. 2000. The autonomic and sensory innervation of the smooth muscle of the prostate gland: a review of pharmacological and histological studies. J Auton Pharmacol 20: 193-206.

Stefanick ML, Smith ER, Szumowski DA AND DAVIDSON JM. 1985. Reproductive physiology and behavior in the male rat following acute and chronic peripheral adrenergic depletion by guanethidine. Pharmacol Biochem Behav 23: 55-63.

TAYlor DC, SteEle JE AND Gayton RJ. 1987. An analysis of the responses of rat striatal neurones to scrotal skin temperature. Brain Res 419: 352-356.

Titus MA, Schell MJ, Lih FB, Tomer KB AND MoHLER JL. 2005. Testosterone and dihydrotestosterone tissue levels in recurrent prostate cancer. Clin Cancer Res 11: 4653-4657.

Wang JM, McKenna Ke, McVary KT and Lee C. 1991. Requirement of innervation for maintenance of structural and functional integrity in the rat prostate. Biol Reprod 44: 1171-1176.

Zempoalteca R, Martinez-Gomez M, Hudson R, CRUZ Y AND LUCIO RA. 2002. An anatomical and electrophysiological study of the genitofemoral nerve and some of its targets in the male rat. J Anat 201: 493-505. 